Article

\title{
Determinants of the sustainability and growth of construction contractors
}

\author{
Abimbola Windapo ${ }^{1, *}$ \\ 1 University of Cape Town1; abimbola.windapo@uct.ac.za \\ * Correspondence: abimbola.windapo@uct.ac.za; Tel.: +27-21-650-2049
}

\begin{abstract}
The focus of research has mainly been on the life cycle approach to project development, while limited attention has been given to the ageing construction companies that make all these activities/processes happen. This paper examines the organisational factors determining the sustainability and growth of building and civil engineering contractors in South Africa. The paper explores whether there are specific organisational factors that aid the sustainable development and growth of contractors in the South African construction industry. The paper analyses data gathered from face-to-face interviews conducted with four established and twelve upgraded and successful building and civil engineering contractors listed on the Construction Industry Development Board's (cidb) Register of Contractors. The aim of the study is to identify the organisational factors critical for sustainable contractor development and growth in South Africa. The study found that organizational factors responsible for the sustainable development and growth of construction contractors include the size of the founding team members, management capabilities, strategic decisions made by founders/leaders and the ability of the company to constantly evolve, adapt and respond effectively to threats/challenges whenever they surface, amongst other findings. Capacity to generalise the results of the study to the large cidb registered contractor group is limited by the smallness of the sample size. Future research should make use of a larger sample size to obtain more general findings. The results of the study imply that the founding team size, experience, entrepreneurial and managerial capabilities, capacities and organisational structures that enable the efficient response of companies to external and internal challenges are key components of the definable arrangements that will support the sustainability and growth of construction organisations. The paper is of value to government departments and agencies such as the cidb and contracting firms in the construction industry.
\end{abstract}

Keywords: cidb; contractor development; entrepreneur; growth; management; sustainability; time

\section{Introduction}

There is only one alternative to sustainability: unsustainability [1] and, a company either grows or declines [2]. According to Ansoff [3], a business firm must go through continuous growth and change, just to retain its relative position. To improve its position, it must grow and change at least "twice as fast as that". Bossel [1] concurred that sustainability involves a time dimension, that there are permanent change and evolution and that the ability for change and evolution must be maintained if systems are to remain viable. The sustainability goal translates more accurately into a target for sustainable development [1].

Sustainable development is defined by [4] to mean the economic development that meets the needs of the present generation without compromising the ability of future generations to meet theirs. In the context of the sustainability and growth of construction firms which is the focus of this paper, sustainable development is defined as the economic survival of construction companies (with a quality beyond mere existence) through the maintenance of basic support systems (work, liquid and fixed assets, skilled workers, and viable network) ensuring that skills and competencies available today are improved upon and not lost to future generations. This definition of sustainable 
development implies that the components of sustainable development include environmental, human and time related factors. In this paper, sustainability and sustainable development of construction organisations will be used interchangeably.

Construction is the bridge between concept and reality [5]. The building industry moulds the environment in which we live by creating the cities, towns, villages that constitute our communities; it also creates the infrastructure and communication networks that define the scope of our communities; it contributes to the economy and provides employment for a variety of participants in manufacturing, finance and investment, consultancy and contracting [6]; it is known to have a huge impact on the environment and as a result, is reputed to have a significant relationship with the sustainable development of the built environment [7].

The focus of this paper is in the contracting sector, which encompasses two major groups building and civil engineering contractors and to a lesser extent, specialist sub-contractors. These contracting enterprises ranging from small to large, interact with each other and with other companies outside the industry. All stakeholders - government, community, customers, shareholders, employees and suppliers - share a common interest that construction firms will continue to grow, so that they will share in their increased prosperity [6].

Research has mainly focused on the life cycle approach to project development - conception, planning, construction and use - and little attention has been given to the ageing firms/contractors that make all these activities/processes happen. The sustainable development of the products of the construction industry is, of course, desirable, but the sustainability of the actors involved in the building process is equally important, because, if these enterprises fail, the skills and expertise available to the construction industry today will be lost to future generations. Further, the construction industry's ability to deliver quality products and services at the right time and competitive prices will be detrimentally affected; its role as a significant employer of labour will be impacted; contribution to government taxes will be lost; and the input to the Gross Domestic Product (GDP) will be negatively affected.

The study reported in this paper examined the factors determining the sustainable growth and development of selected large and successful contracting organisations in South Africa, with the aim of discovering whether there is a recipe for the sustainability and growth of construction companies. In a different view, Bossel [1] argues that sustainability is a dynamic process and unlikely to be permanent. While Harris and McCaffer [2] opined that no hard and fast rules could be set for commercial success, but certain definable arrangements are desirable for any business.

To examine if there are general factors and clearly definable arrangements that determine the sustainability and growth of construction contractors, the structure of the South African construction industry are reviewed in the following section - to understand if shortages of contractors are likely to be expected in future. The next section presents a literature review of the factors that determine the sustainable development and growth of construction firms. The following section presents the results of the personal interviews conducted with sixteen selected established and large contractors that have been upgraded and listed on the cidb Register of Contractors. The final section proposes definable arrangements likely to aid the sustainability and growth of contractors.

\section{Structure of the South African Construction Industry}

South Africa's building and construction sector play a fundamental role in the country's economic development through its potential to employ a large number of people. Despite some slow periods, the construction industry has shown an overall trend of improvement since 2000. Record expansion in construction activity helped South Africa's Gross Domestic Product (GDP) grow by $4.7 \%$ in the first quarter of 2007, achieving 34 consecutive quarters of economic growth since $1998-$ the longest upswing in the country's history [8].

Table 1 shows the percentage distribution of the public sector awards by value, the number of contractors to which the awards were made for South Africa as a whole between 20161 st quarter and 2016 4th quarter (a period of 12 months) to contractors listed in Grades 2 to 9 on the cidb Register of 
Contractors - the size of the contractors ranging from the smallest in Grade 2 to the largest in Grade 9. Information on the distribution of tenders to Grade 1 contractors is noted to be "very limited and unreliable" [9, p. 5].

Table 1. Distribution of number of contractors by cidb Grade and public sector awards and by value 2016 1st Quarter and 2016 4th Quarter

\begin{tabular}{|c|c|c|c|c|c|c|}
\hline \multirow[t]{2}{*}{$\begin{array}{l}\text { Project } \\
\text { Grade }\end{array}$} & \multicolumn{4}{|c|}{$\begin{array}{l}\text { No of Contractors on Register } \\
\text { (April 2017) }\end{array}$} & \multicolumn{2}{|c|}{$\begin{array}{l}\text { Public Sector Awards by } \\
\text { Value } \\
\text { (2016 Q1 to 2016 Q4) }\end{array}$} \\
\hline & $\begin{array}{l}\text { General } \\
\text { Building }\end{array}$ & $\begin{array}{c}\text { Civil } \\
\text { Engineering } \\
\end{array}$ & $\begin{array}{l}\text { Total No of } \\
\text { Contractors } \\
\end{array}$ & Percentage & $\begin{array}{c}\text { General } \\
\text { Building }\end{array}$ & $\begin{array}{c}\text { Civil } \\
\text { Engineering } \\
\end{array}$ \\
\hline 9 & 48 & 75 & 123 & $1.2 \%$ & $28 \%$ & $32 \%$ \\
\hline $7 \& 8$ & 535 & 685 & 1220 & $11.5 \%$ & $60 \%$ & $56 \%$ \\
\hline $5 \& 6$ & 1166 & 1374 & 2540 & $24.0 \%$ & $10 \%$ & $9 \%$ \\
\hline 2 to 4 & 3417 & 3263 & 6680 & $63.2 \%$ & $3 \%$ & $3 \%$ \\
\hline Total & 5166 & 7154 & 10563 & $100 \%$ & $100 \%$ & $100 \%$ \\
\hline
\end{tabular}

Source: [10]

Table 1 shows that the construction sector is made up of a few large firms listed in Grades 7 -9, constituting $12.7 \%$ (1343) of the firms registered with the cidb. The table also illustrates that the structure of the construction industry also follows the structure of the public sector contracts awarded to the industry. It reveals that $88 \%$ of public sector contracts for the period presented were awarded to the large General Building and Civil Engineering Contractors. Table 1 also indicates that 13\% (General Building) and 12\% (Civil Engineering) of public sector contracts were awarded to Grade 2 to 6 comprising $43.4 \%$ (General Building) and 43.6\% (Civil Engineering) of the firms (Grades 2 to 9) registered on the cidb Register of Contractors [10].

The composition of the supply and demand for construction activities in South Africa presented in Table 1 is consistent with the nature of the construction industry. Despite the fact that the core principles of sound business management are commonly required in all enterprises [12], they are often not evident in construction firms, given the relatively low level of start up capital required and ease of entry into the sector compared with other industries [11-12]. Consequently, many construction firm owners have neither the technical training nor the management expertise required to start their businesses.

Another characteristic of the building industry is that most of its high valued contracts are often large-scale which cannot be sub-divided or awarded piece meal, and often require a high level of management, financial solvency and technical capability skills [13] most frequently found amongst the Grade 7 to $9 \mathrm{cidb}$ registered contractors [14]. Figures 1 and 2 show trends in the growth of numbers of contractors in the cidb Register of Contractors in Grades 2 to 8 over the ten years reported in the 2008 Q3 Quarterly Monitor to 2017 Q1 Construction Monitor, for both the General Building (GB) and Civil Engineering (CE) divisions. 


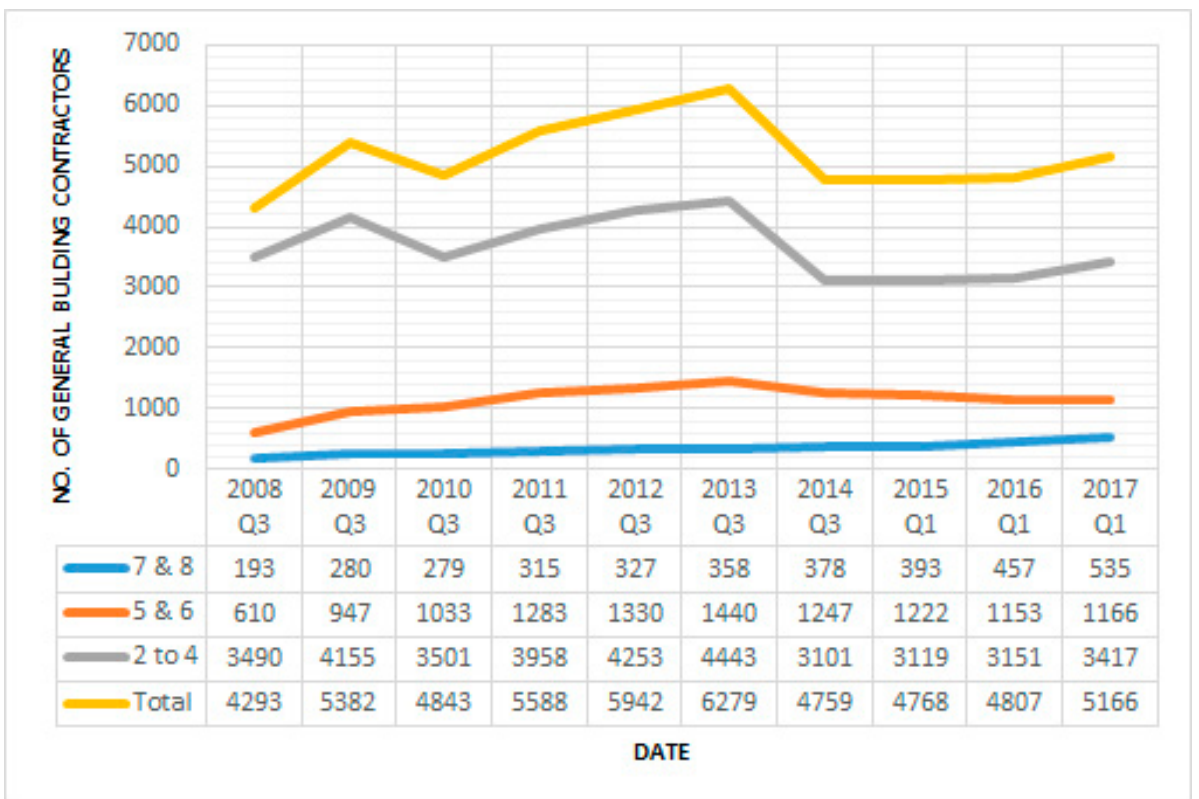

Figure 1. Distribution of cidb registered general building contractors by Grade from 2008 Q3 to 2017 Q1 (Source: [10], [14-22])

Figures 1 and 2 indicate a trend in the number of GB contractors registered in Grades 2 to 4 increased between 2008 and 2009 before falling back in 2010, and then surged rapidly to a high in 2013 along with CE contractors. Registered Grades 2 to 4 GB contractors saw their lowest figures between 2014 and 2017, while Grades 2 to 4 CE contractor numbers rose steadily during the same period. The number of GB contractors registered in Grades 5, and 6 gradually increased from 2008 to a high in 2013 and then fell back to marginally higher numbers in 2017 than were recorded in 2008. A similar trend can be observed in Grades 5 to 6 CE contractors.

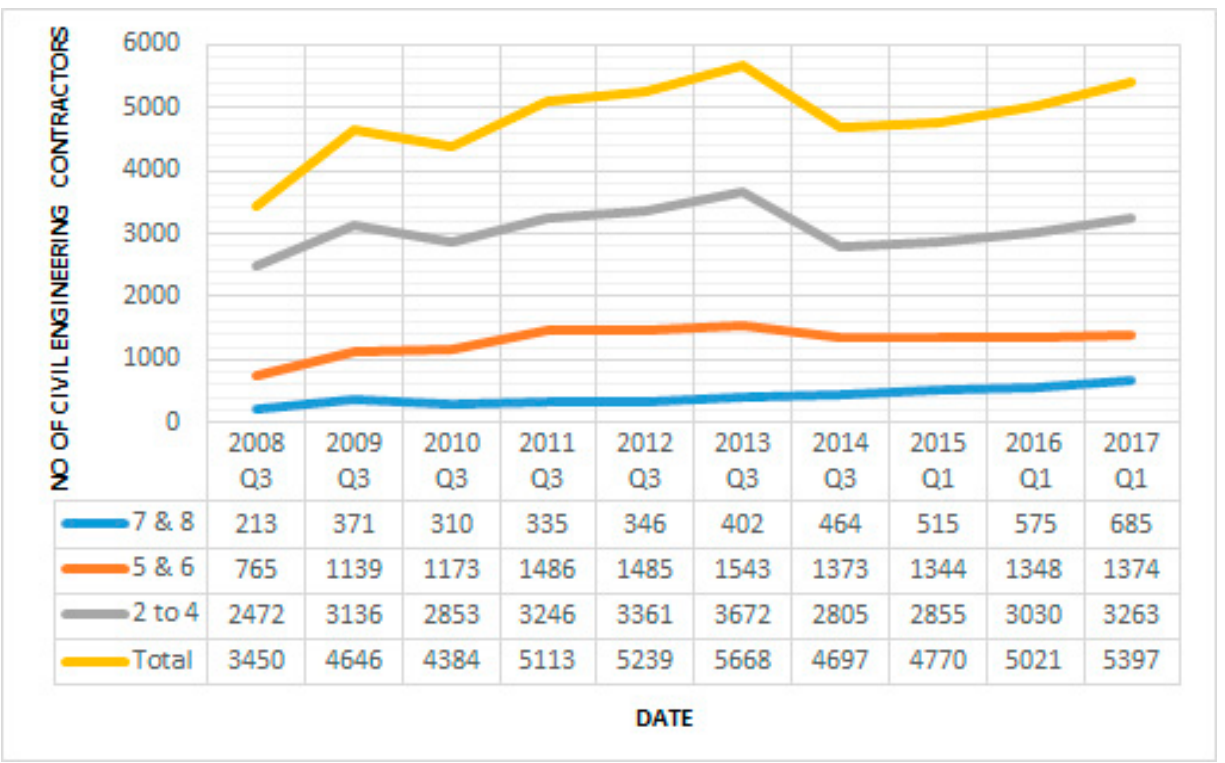

Figure 2. Distribution of cidb registered civil engineering contractors by Grade from 2008 Q3 to 2017 Q1 (Source: [10], [14-22])

Grades 7 to 8 contractors recorded a steady growth and slight decline in numbers from 2008 to a high in 2017. This was evident in both the General Building and the Civil Engineering divisions. Given that the totals given in Figures 1 and 2 represent the weighted averages of the trends described above, the overall trend in both divisions was growth in numbers between 2008 and 2009 and a decline between 2009 and 2010, and then surging rapidly to a high in 2013 before falling again in 
2014, but to totals exceeding the 2008 numbers. Overall, contractor numbers in both divisions show a continuous growth between 2014 and 2017.

The data presented suggest that the noticeable movements and decline in the total number of contractors listed on the cidb Register of Contractors over the years examined can be attributed to the increase and decline in the number of lower level contractors on Grades 2 to 4 (see Figures 1 and 2). Contractor attrition or failures in these Grades is a source of concern because it is from this pool of contractors that sustainable development and growth start. Ofori and Chan [23] noted that studies on growth strategies adopted by contractors often highlight the relatively hazardous nature of the process, and the high mortality rates among firms owing to the nature of construction activity.

\section{Review of Factors Determining Sustainable Development and Growth of Companies}

Based on earlier literature and studies by $[1,2,8],[24-36]$, the factors determining a company's sustainable development and growth and their indicators are presented in Table 2.

Table 2. Factors determining business sustainable development and growth

\begin{tabular}{cll}
\hline S/No & Factors & Indicators \\
\hline a. & Environment & $\begin{array}{l}\text { Founding environment including government policies/regulations; } \\
\text { Type of market - growth stage or growing; } \\
\end{array}$ \\
& & Level of competition within the market (threats to business survival); \\
& General economic conditions; \\
& Industry structure.
\end{tabular}

Sources: [1,2,8], [24-36]

Stinchcombe [24] and Eisenhardt and Schoonhoven [25], emphasised the importance of environmental factors such as demand, industry maturity, economic expansion and barriers to entry into the industry by contractors. They found that a founding environment affects company growth; that companies founded in growth-stage markets are more likely to become larger than those found in emergent or mature markets; and competition at founding did not affect firm growth.

Boyd [8] noted that, since 1995, the government of South Africa has worked and played a key role in opening the doors and at putting various strategies in place to assist historically disadvantaged individuals (HDIs) to participate in construction. To this end, the government put in place focused policies of economic empowerment such as the Black Economic Empowerment (BEE) preference score of $10 \%$ used in tender adjudication and access to capital for business development, to make it easier for market penetration by HDIs. In a study of factors influencing the development of 
construction enterprises in Singapore, Ofori and Lean [34] found out that the government's role in construction enterprise growth appears to be key.

The organisational factor according to Stinchcombe [24] and Eisenhardt and Schoonhoven [25], is an issue responsible for company success. Ofori and Chan [23] found out that firms have to be established on a strong footing comprising of a strong founding team to be successful and grow in any market (growth or non-growth markets).

Snell and Dean [31] and Wiklund and Shepherd [32], noted that the human capital of a small manager consists of skills and knowledge - obtained through education and experience - that assist in running the business successfully. A consistent finding for general human capital is that educated individuals are more likely to run faster-growing small businesses than those who are less educated [31]. Applied to the investigation, it implies that although competencies are required for enterprise growth, having an educated founder will enable the company to grow at a faster rate.

Eisenhardt and Schoonhoven [25] found out that top executives make a difference in how companies grew and that the success and growth of businesses can be attributed to the unique abilities of the founder/entrepreneur, his personality, his dreams and his flaws. Strong teams with the requisite experience and education tend to move more quickly, get more done and make fewer mistakes than other teams. While, Harris and McCaffer [2] noted that founders/entrepreneurs who are managers of the team should be people of experience, understanding and vision, and should have enough confidence to delegate responsibilities and stand by decisions made. Wiklund and Shepherd [32] in their study of small business managers' growth aspirations and the level of growth achieved determined that small business managers' aspirations to expand their business are positively related to actual growth. Stinchcombe [24] and Eisenhardt and Schoonhoven [25] found that another factor underlying the failure of young organisations is their limited financial resources and that company growth is dependent on the abundance of this.

As a company grows and become successful, certain definable business arrangements start to evolve. These definable business arrangements come as a result of the ability of the company to transform from a small local company to a large successful company with branches/sub-divisions in different locations within a country or across its borders. In its bid to penetrate the construction market to obtain a larger portion of the market share or "pie", which helps the company in improving its turnover and in spreading its risk, the successful large contractor diversifies into providing clients with new services and products. As a business enterprise grows and becomes successful, to undertake more work and employ more labour, the problem of coordinating the various activities and numerous personnel would gradually expand beyond the capacity of one individual. The organisation structure is therefore an indication of the fact that a company has grown/developed.

In sustainable development and growth, the issue of time therefore becomes a factor. Apart from putting the necessary components in place, a company must be able to adapt to the changes in time. Ofori and Chan [23] noted that strategies adopted by firms are time related to economic conditions during economic booms and recessions. The ability of a firm to respond to threats is a factor in determining its sustainability and viability; Bossel [1] determined that if responses cannot keep up with the threats, viability and sustainability are at risk.

Sustainable development according to Bossel [1] implies constant evolutionary, self-organizing and adaptive change, and the widest possible spectrum of adaptive responses to new challenges should be available for potential adoption. The greater the number of different innovative options, the better because diversity allows timely adaptation by offering options, some of which may turn out to be better suited to cope with present conditions than others [1]. Mitra and Pingali [33] reported that lack of adequate time to expand is perceived as a major constraint for the growth of small enterprises in India.

Finally, companies' annual performance is an indicator of whether they are likely to grow successfully and sustainably because once companies become successful, other customers, investors and allies are attracted to what appears to be a successful venture. In turn, suppliers become more willing to do business with these apparently successful ventures, and over time, the company growth becomes a self-fulfilling prophecy, as success breeds success [25]. 
The empirical work undertaken in the current study compares the configuration of the sustainable development factors - organization, structures and system; and time dependent factors identified in Table 2 with what is revealed through personal interviews with twelve upgraded and four established construction firms listed on the cidb Register of Contractors because, while company sustainability and growth can be attributed to environmental, organizational and time dependent factors, contracting firms are unable to control issues related to environmental factors.

\section{Survey Methods}

All 62 successful contractors who have been upgraded at least three times within five years and listed in the cidb Register of Contractors were sent an invitation for an interview, out of which, 14 $(27 \%)$ accepted the invitation to be interviewed. While this response rate may be perceived as low, it is adequate for this study. The respondents covered a broad range of work and location groupings. Respondents were located in five of the nine provinces namely - Western Cape, Gauteng, North West, Kwa-Zulu Natal and the Free State. Personal interviews were conducted with either the founding member, CEO or Director of 12 of the successful contractors, using an interview protocol to understand and document the obvious factors responsible for contractor growth and success. In addition to the upgraded contractors interviewed, the CEO or Director of four established Grade 9 contracting organisations were also interviewed and used as a control group for the study.

The interviews were conducted at the respondents' places of work. The type of information required was sent to the CEOs/Directors in advance with the request for an invitation for an interview.

\section{Results and Discussion}

\subsection{Contracting Companies' Distribution by Date of Incorporation}

Table 3 presents the year upon which the contractors interviewed started operations.

Table 3. Year in which contracting companies were incorporated

\begin{tabular}{lcc}
\hline Year of incorporation & Frequency & Percentage \\
\hline Before 1994 & 4 & $33.3 \%$ \\
Between 1994 and 1999 & 4 & $33.3 \%$ \\
Between 2000 and 2004 & 4 & $33.3 \%$ \\
2005 and after & 0 & 0.00 \\
Total & $\mathbf{1 2}$ & $\mathbf{1 0 0 \%}$ \\
\hline
\end{tabular}

Table 3 reveals that none of the contractors consulted was incorporated after the coming into operations of the cidb Contractor Register in 2004. It emerged that four were founded before the democratic elections in South Africa in 1994, another four were established in the 1st democratic dispensation that is between 1994 and 2000 and four others were established between 2000 and 2004 when the cidb Contactor Register came into operation.

\subsection{Organizational Factors}

The roles of founders are identified as a critical factor in shaping young firms. The study sought to find out if the characteristics of the companies' founding team/entrepreneurs are consistent with the findings of Eisenhardt and Schoonhoven [25]. Also to know if these founding team factors can be used to explain the successes and growth of the upgraded construction companies, i.e. whether the firms that grew the most combined synergistically founding in a growth market with a superior topmanagement team.

\subsubsection{Founding Top Management Team}


It emerged from the interviews that at founding, a significant number of the companies were owned by teams of two and three owners who had more than six years of work experience in the construction industry; a major number of team members who had past experience together in a construction company; and importantly, the experience acquired by the team members were varied but relevant. Some acquired experience in human resources, while others were adept at tendering, financial management, construction operations and plant management.

The results also suggest that the entrepreneurs appeared to begin ventures in the construction industry sector in which they knew and were experienced in for example if they were experienced in civil works, they founded civil engineering companies and if they were experienced in construction work they started off general building companies, rather than in sectors of the industry that are seen as attractive. As they grow, it appears that the companies tend to shift towards more lucrative and rewarding sectors of the industry (such as property development).

It emerged that there is a perceived balance between the highest educational qualifications possessed by the founders. When cross-tabulated in company terms, there are only four companies out of the twelve businesses in which there are owners with no form of tertiary education at all and these are found in the companies in which there are only sole owners and three of which were founded before 1994.

The study also reveals that a significant number of the founding owners have no professional qualifications. This is only indicative but seems to suggest that successful construction companies do not need to have owners who are professionally qualified.

The results of the study imply that the size of the founding team, founding owners' experience and previous experience together, and members' varied experience in the construction industry is responsible for the companies' growth. What appears to have happened is consistent with findings by Eisenhardt and Schoonhoven [25] who determined that top executives make a difference in how companies grew.

\subsubsection{Weaknesses of the company and founder and threats to business survival at inception}

The results of the study suggest that a significant number of the companies considered their biggest weakness to be the lack of financial resources. Other weaknesses acknowledged by the respondents are those that had to do with their personal traits such as being weak, impatient and irritable, being a white company and being female. The owner of the female company experienced a lot of challenges trying to sell a female company and also in clients inability to acknowledge the fact that a female company is capable of producing high-quality work.

Other company drawbacks identified by the respondents include - lack of business experience, education and difficulty in finding and retaining knowledgeable and qualified employees. Operational challenges and having to manage highly dispersed sites were found to be a major limitation at inception by one of the contractors surveyed. According to the respondent, "the location of the site, not only how far it is to a manufacturer of building materials, but the nature of the site on which the construction took place was a major constraint".

The ability of the founders to navigate the threats to survival and their weaknesses will determine if the company would grow or die. Following the interviews, it emerged from the findings that the business owners believed that the greatest threat to their business survival at inception stage was and still is the lack of adequate financial resources by clients both in the public and private sectors and the payment methods which are often delayed in public sector projects. According to the founders/entrepreneurs, this tends to impact negatively on their cash flow and working capital and almost causing the death of their companies.

\subsubsection{Strategic Decisions made by Company Founders/Leaders:}

To survive and grow, construction companies need to make certain policy decisions and develop specific strengths. The respondents were asked to give an indication of which strategies resulted in the success of the enterprise. The respondents were unanimous in acknowledging that the most important strategy responsible for their company's sustainability, growth and success were due to 
their decision to develop a strong financial base for the enterprise. Knowing that a factor threatening their existence at the inception stage was both lack of funds and the failure of clients to pay as and when due.

Another strategy acknowledged by the respondents is having a good track record regarding high-quality products at the right time and thereby pleasing the client. Although some of the interviewees declared that this should not be a strategy because the reason for being in business and the only reason a company will stay in business is to provide excellent quality services at the right time. If this is not done, the company will not be in business.

However, the respondents acknowledged the importance of suppliers and the need to pay them timeously even if the client is yet to pay for services rendered. This according to them is because $5 \%$ discount/increase or credit facilities offered by the suppliers go a long way in improving company profits and cash flow. A contractor further opined "companies should maintain good relationships with their suppliers as bulk discounts are helpful in reaching profit levels."

The respondents also employ the acquisition of construction equipment and other fixed assets e.g. land as a company sustainability and growth strategy. It emerged from the interview responses that investment in construction equipment helps in three ways - it can be used as surety for loans, secondly, whilst being used as surety, the equipment can be put to use on projects, and when the loan is obtained, the construction company does not need to go out and hire the equipment. Saving money both ways. Thirdly, the construction equipment when owned is helpful while tendering for construction projects in which there is fierce competition as the ownership of equipment is usually a requirement on construction tenders.

The respondents revealed that they made use of certain procurement strategies such as Design and Build and Joint Venture alliances in their bid to procure jobs. They offered clients services in which they will both be the designers and constructors, saving the customer money and also effectively helping the company procure the job and keeping out other competitors. Although Joint Venture alliances were not used as a strategy to access specialized technology/know-how, it was used as a strategy to procure jobs.

Following the responses from the interviews, it emerged that if a company were able to train and retain its workforce, it would help the company in effectively executing its business operations, thereby leading to sustainability, success and growth. Furthermore, a respondent asserted verbatim that "when personnel in an organization are not adequately trained with technical skills, the right attitude and work ethos, that company will fold up because companies making huge profits are in the habit of training their workers". Another respondent disclosed that in their business all employees go on a compulsory one-week retreat/training programme at least once every year.

\subsection{The Role of Time and Evolution}

All the companies investigated can currently be said to be at the stability/maturity stage having grown successfully, and through the years some established as far back as 1976 have evolved structures in response to the challenges faced. The study, therefore, sought to find out what were the structures evolved? It emerged that though most of the companies started out with very little or no financial capital, a significant number of these successful contractors have been able to plough money back into the business. Implying that a characteristic of successful contractors that evolves over time is its financial capacity.

The typical characteristic of a developed contractor regarding the value of their fixed assets made over the years also emerged from the study, which revealed that all the companies studied had significant investments in construction equipment, land and buildings, which they use as instruments of production that enabled them to earn revenue. Accordingly, the investment in fixed assets grew steadily on the average for the companies studied. The study results also indicate that as companies become more successful, there is a corresponding increase in the number of employees that they have.

Also, certain business arrangements start to evolve. Amongst these business arrangements which comes as a result of the ability of the company to transform from a small local company to a large successful company with branches/sub-divisions in different locations within a country or 
across its borders. The geographical spread of the companies within and outside South Africa was investigated. The results show that the typical geographical structures emerging amongst the developed contractors are that a significant number (12) of these firms are spread across at least two different locations, and that seven and six of the companies have established their presence in Gauteng and the Western Cape Provinces respectively. The results seem to suggest that success, sustainability and growth of the companies into large business concerns will have to do a lot with the ability of the founders/leaders to identify and diversify into new and more profitable markets embodied by areas such as Guateng and the Western Cape Provinces in South Africa.

In its bid to penetrate the construction market in order to obtain a larger portion of the market share or "pie" and respond to new challenges, which helps the company in improving its turnover and in spreading its risk, the successful developed contractor investigated have divisions with specialties in at least three product markets - civil engineering contracting, general building contracting and property and housing development. It also indicates that successful companies are likely to be diversified into more than one service and or product area as it grows.

It can be inferred from these results that these market strategies/affiliations of operating in more than one specialist service/product area, used by the companies has allowed for more market penetration by the companies and also providing adaptive response to new challenges, purposely increasing their market share and turnover and making it possible for these businesses to grow more quickly, sustainably and successfully.

The study sought to find out the span of responsibility and divisions within the companies investigated that have resulted as a response to the challenge of managing the company operations over time. The results show that in the successful companies investigated for which information was made available, leadership/management in the companies spanned across two managerial steps and chain of command/hierarchy, a significant number of companies had three stages of management responsibility. The results suggest that the growth of the companies is consistent with that which was described by Steinmetz [37], that a small business - if it is succeeding - is inescapably committed to living through three critical phases and four stages of growth which he called direct supervision, supervised supervision, indirect control and divisional organization, based largely on the development of the manager and founder through these stages.

The organization structures developed by a significant number of these successful companies reveal that the firms have attained the indirect control and divisional organisational stage in which the founders/leaders are now "managing the managers". In doing this, the founders/leaders have a clear idea of what has to be done, when and by whom [38].

Furthermore, the results illustrate that the companies studied have at least three main division/sections, the three most popular being Project/Contract Management department, Finance, Human Resources/Admin and Commercial/Marketing/ Procurement in order of commonality. This suggests that the companies investigated have developed and recruited management employees that fulfil other necessary requirements in a construction company. The organization structure can therefore be said to be an indication of the fact that a company has sustainably grown/developed because smaller contracting businesses only have the management rolled into a single entity embodied by the founder/leader and the followers/workers rolled into a single entity [6].

\section{Conclusions and Recommendations}

From the interviews of successful upgraded and large contractors registered on the cidb Register of Contractors, information provided by the cidb and the literature search made to support the study findings, it was established that there are opportunities to sustainably develop and grow small contracting firms into large contractors in South Africa principally because the South African economy is a growing market; and that there is a declining trend in the total number of contractors listed in Grades 5 and 6 General Building and Civil Engineering contractors on the cidb Register of Contractors between Years 2013 and 2017. Furthermore, it was established that the organizational and time dependent factors responsible for the sustainability and growth of construction contractors consist of: the size of the founding team at inception, members, experience before setting up the 
company, founding owners' past experience and previous experience together, and members varied expertise in the construction industry experience are responsible for the companies' growth and development. Strong teams - having the requisite experience and education - developed faster; the ability of the founders and entrepreneurs to make use of their management capabilities, the company strengths embodied in the knowledgeable and qualified employees and to overcome the companies lack finance and the difficulty of securing payment from government agencies and private developers which threatened the survival of the enterprise; strategic decisions made by the founders/leaders including developing a strong financial base for the business, excellent track records, procurement strategy used and formulating and maintaining a strong workforce; and the ability of companies to constantly evolve, adapt and respond effectively to threats/challenges whenever they surface.

Based on these finding, the study concludes that contractors were particularly middle level ones are unable to develop and grow sustainably, and that low-level construction firms need to make use of growth strategies to develop sustainably and successfully, and this requires time. It is therefore recommended that founders/owners of lower ranked contracting firms hoping to develop sustainably should: - allow enough time for the company to develop organically, steadily and gradually. Entrepreneurs and business leaders should therefore not stretch themselves out too thinly, taking on more jobs than their capacities and capabilities can cope with so as to avoid burnouts and failure; get the necessary management experience; attend and also send their employees to regular and relevant training workshops and seminars for continuous development; reorganize in order to develop strong management teams; and to provide a suitable environment and structure for growth by introducing new blood into the company based on the capacity lacking in the organization; must be able to train other managers/successors and creating opportunities and avenues through which these successors would also grow and develop; and invest in fixed assets which include plant and equipment and maintain an adequate cash reserve.

However, even though a firm has grown successfully and sustainably, the issue of what happens to it after the departure of the founder/entrepreneur becomes a matter of major concern. It is important for the founder/entrepreneur to be capable of handing over control to the next generation of leaders.

Acknowledgements: The author is grateful to the Construction Industry Development Board (cidb) for the use of its materials and funding the project from which this paper was developed and also to Abdulrauf Adediran for his help in secondary data gathering.

\section{References}

1. Bossel, H. Indicators for Sustainable Development: Theory, Method, Applications; International Institute for Sustainable Development (IISD): Canada, 1999.

2. Harris, F.; McCaffer, R. Modern Construction Management, 5th ed.; Blackwell Science: Oxford, 2001.

3. Ansoff, H.I. Strategies for Diversification. Harvard Business Review 1957, 35, 5, 113-124.

4. Brundtland, G.H. Our Common Future: Report of the World Commission on Environment and Development; Oxford University Press: Oxford, 1987.

5. Vanegas, J.A. Road map and principles for built environment sustainability. Environ. Sci. Technol. 2003, 37, 23, 5363-5372.

6. Calvert, R.E.; Bailey, G.; Coles, D. Introduction to Building Management; 6th ed.; Butterworth-Heinemann: Oxford, 1995.

7. Howard, N. Sustainable Construction - the Data; Centre for Sustainable Construction: UK, 2000. http://projects.bre.co.uk/sustainable/SusConstructionData.pdf. [Accessed 23/4/2017].

8. Boyd, M. Women in building and construction: a gradual transformation. Women on Site 2010, 1, 7-10.

9. Construction Industry Development Board (cidb), Targeting for Contractor Development Programmes; cidb: Pretoria, South Africa, 2010.

10. Construction Industry Development Board (cidb), cidb Construction Monitor: Supply \& Demand, April, Q1 2017; cidb: Pretoria, South Africa, 2017.

11. Hillebrandt, P.M. The management of large UK contracting firms - theory and practice. In Lansley, P.R.; Harlow, P.A., Eds.; Managing Construction Worldwide: Volume 2 - Productivity and Human Factors in 
Construction. Proceedings of the 5th International Symposium on the Organisation and Management of Construction, CIB-W65, London, 7-10 September, 1987, pp. 919-926.

12. Wahab, K.A. The Place of Construction Management in the Economic Development of Nigeria. Proceedings of the Annual Conference of the Nigerian Institute of Building (NIOB), Port Harcourt, Nigeria June, 1989.

13. Ofori, G. Challenges for construction industries in developing countries. Proceedings of the Second International Conference of the CIB TG 29, Gaborone, Botswana, Nov, 2000, pp. 1-11.

14. Construction Industry Development Board (cidb), cidb Quarterly Monitor, October; cidb: Pretoria, South Africa, 2010.

15. Construction Industry Development Board (cidb), cidb Quarterly Monitor, October; cidb: Pretoria, South Africa, 2008.

16. Construction Industry Development Board (cidb), cidb Quarterly Monitor, October; cidb: Pretoria, South Africa, 2009.

17. Construction Industry Development Board (cidb), cidb Quarterly Monitor, October; cidb: Pretoria, South Africa, 2011.

18. Construction Industry Development Board (cidb), cidb Quarterly Monitor, October; cidb: Pretoria, South Africa, 2012.

19. Construction Industry Development Board (cidb), cidb Quarterly Monitor, October; cidb: Pretoria, South Africa, 2013.

20. Construction Industry Development Board (cidb), cidb Quarterly Monitor, October; cidb: Pretoria, South Africa, 2014.

21. Construction Industry Development Board (cidb), cidb Construction Monitor: Supply E Demand, April, Q1 2015; cidb: Pretoria, South Africa, 2015.

22. Construction Industry Development Board (cidb), cidb Construction Monitor: Supply E Demand, April, Q1 2016; cidb: Pretoria, South Africa, 2016.

23. Ofori, G.; Chan, S.L. Growth paths of construction enterprises in Singapore, 1980 - 98 . Engineering Construction and Architectural Management 2000, 7, 3, 307-321.

24. Stinchcombe, A.L. Social Structure and Organizations. In Handbook of Organizations; March, J.G., Ed.; Rand McNally: Chicago, 1965; pp. 142-193.

25. Eisenhardt, M.K.; Schoonhoven, C.B. Organizational Growth: Linking Founding Team, Strategy, Environment and Growth among U. S. Semi-Conductor Ventures, 1978 - 1988. Administrative Science Quarterly 1990, 35, 504-529.

26. Cooper, A.C. Strategic management: New Ventures and Small Business. In Strategic Management: A New View of Business Policy and Planning; Schendel, D.E.; Hofer, C.W. Eds.; Little Brown and Company: Boston, 1979; pp. 316-327.

27. Boskin, M.J. The fiscal environment for entrepreneurship. In The Environment for Entrepreneurship; Kent, C.A., Ed.; Lexington Books: Lexington, 1984; pp. 59-68.

28. Chilton, K.W. Regulation and the entrepreneurial environment. In The Environment for Entrepreneurship; Kent, C.A., Ed.; Lexington Books: Lexington, 1984; pp. 91 -116.

29. Sandberg, W.R. New Venture Performance: The Role of Strategy and Industry Structure; Lexington Books: Lexington, 1986.

30. Covin, J.G.; Slevin, D.P. Strategic Management of Small Firms in Hostile and Benign Environments. Strategic Management Journal 1989, 10, 75-87.

31. Snell, S.A.; Dean, J.W. Integrated manufacturing and human resource management: a human capital perspective. Academy of Management Journal 1992, 35, 3, 467-504.

32. Wiklund, J.; Shepherd, D. Aspiring for, and Achieving Growth: The Moderating Role of Resources and Opportunities. Journal of Management Studies 2003, 40, 1919-1941.

33. Mitra, R.; Pingali, V. Analysis of growth stages in small firms: a case study of automobile ancillaries in India. Journal of Small Business Management 1999, 33, 3, pp. 62-75.

34. Ofori, G.; Lean, C.S. Factors influencing development of construction enterprises in Singapore. Construction Management and Economics 2001, 19, 2, 145-154.

35. Gunhan, S.; Arditi, D. Factors affecting international construction. Journal of Construction Engineering and Management 2005, 131, 3, 273-282. 
36. Phelps, R.; Adams, R.; Bessant, J. Life cycles of growing organizations: A review with implications for knowledge and learning. International Journal of Management Reviews 2007, 9, 1, 1-30.

37. Steinmetz, L.L. Critical Stages of Small Business Growth, when they occur and How to Survive Them. Business Horizons 1969, 12, 1, 29-36.

38. Rush, H.; Bessant, J.; Hobday, M. Assessing the technological capabilities of firms: developing a policy too. RED Management 2007, 37, 3, 221-236. 